り明らかにする。

試験体は同一断面で, せいのみを変化させた表 1 の3 種を準備し, 実験は図 3 に示すセットアップで, 面外曲げ・面内曲げ・圧縮・引 張について行う。面外曲げ試験では, 仕上げガラス付きの試験体に ついても載荷を行い, 仕上げが剛性・耐力に与える影響を調査する。 接合部ノードには, 表 2 に示す構造用鋼材 SM490 $\left(\sigma_{y}=338 \mathrm{~N} / \mathrm{mm}^{2}\right)$ またはダクタイル鋳鉄 $\operatorname{FCD} 500\left(\sigma_{y}=353 \mathrm{~N} / \mathrm{mm}^{2}\right)$ を使用する。

\section{2 面外曲げ試験}

図 3(a)の面外曲げ試験の結果得られた曲げモーメント一接合部回 転角関係 $\left(M-\theta_{c}\right.$ 関係)を図 4 に, その内試験体 $\mathrm{S} 100 \mathrm{~L}$ 各部の曲げモー メント一歪関係を図 5 に示す。各試験体の $M-\theta_{c}$ 関係は概水弾塑性 型の挙動を示し，梁せいごとに同程度の剛性・耐力を示した。図 5 に示すように，接合部全体の降伏はノードへの歪の集中とほぼ同時 に発生し, 変形もノードに集中しており(写真 2), ノードの耐力が接 合部全体の耐力を決定していることがわかる。ボルトは早期に離間 するものの, 降伏・破断には至らなかった。鋼材ノードは十分な変 形性能を示す一方, 鋳鉄ノードでは梁せい $h_{b}=200 \mathrm{~mm}$ の試験体にお いて, $\theta_{c}=0.05 \mathrm{rad}$ 前後で写真 3 に見るような龟裂を発生し, 耐力低 下を生じた。梁材長さ $l_{b}$ による剛性・耐力の差異は微小であり, 面 外せん断に対する影響は小さいと考えられる。また，ガラスはシー ル部で変形したため, 発生応力は微小であり, 仕上げの剛性・耐力 への寄与は小さい。写真 4 に見るように, 仕上げガラスは $\theta_{c}=0.11 \mathrm{rad}$ まで破壊せず追従した。

得られた $M-\theta_{c}$ 関係に, General-Yield 法(以下 GY 法)を援用し, 戝 6, 表 3 に示す過程でトリリニア型の折れ線でモデル化し, 一次剛性 $K_{e l}$ および二次剛性 $K_{p l}$ を算出した。以降, 第一折れ点での $M$ の值 を降伏曲げモーメント $M_{y}$ とし, 第二折れ点での $M$ の值を終局曲げ モーメント $M_{p}$ と定義する。得られた剛性・耐力を表 4 に示す。

次に, 鋼材ノードを対象として有限要素法 ${ }^{4}$ による実験の再現解析 を行う。解析モデルは, 後述するリング式との比較に用いる単純化 した中空円筒単体に加力する円筒モデルと, 実際のノード形状を正 確に再現したノードモデル，実験同様端部ブロックや梁材まで含め た接合部モデルを設定する(図 8)。

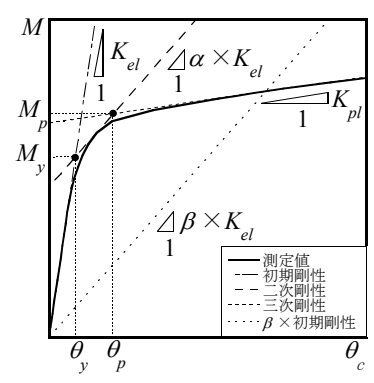

図 6 降伏点の決定方法
表 3 各試験体・解析モデルの係数

\begin{tabular}{|c|c|c|c|c|}
\hline & & 試験体名 & $\alpha$ & $\beta$ \\
\hline & 面外 & 鋼材ノード & 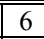 & 6 \\
\hline & 曲げ & 鋳鉄ノード & 6 & 3 \\
\hline & & $h_{b}=100[\mathrm{~mm}]$ & 5 & 10 \\
\hline 実験 & & $h_{b}=150[\mathrm{~mm}]$ & 5 & 6 \\
\hline & & $h_{b}=200[\mathrm{~mm}]$ & 4 & 4 \\
\hline & & 圧縮 & 5 & 3.5 \\
\hline & & 引張 & 5 & 6 \\
\hline & & 面外曲げ & 6 & 6 \\
\hline 䱢 & & 面内曲げ & 4 & 4 \\
\hline & & 圧縮 & 5 & 8 \\
\hline & & 引引張 & 2.5 & 6 \\
\hline
\end{tabular}

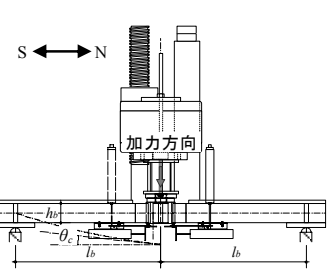

(a) 面外曲げ試験

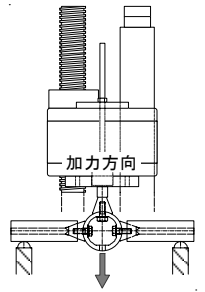

(b) 面内曲げ試験 (c) 圧縮試験 図 3 各種試験の試験体セットアップ図

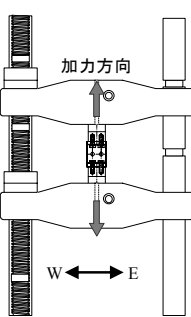

(d) 引張試験

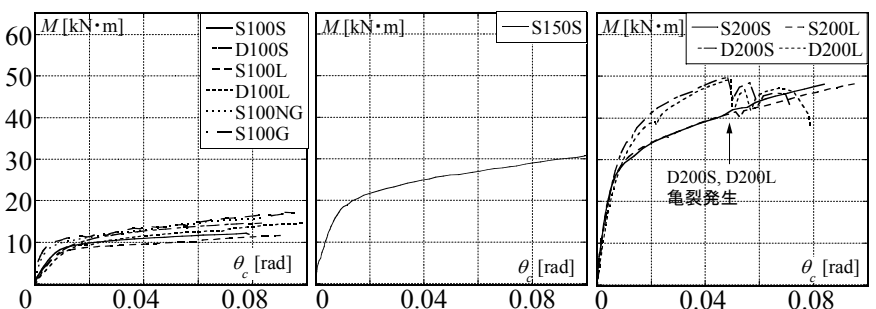

$\begin{array}{ll}\text { (a) } h_{b}=100 \mathrm{~mm} & \text { (b) } h_{b}=150 \mathrm{~mm}\end{array}$

図 4 面外曲げ試験体の $M-\theta_{c}$ 関係

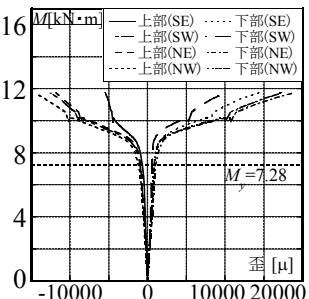

(a) 接合部ノード

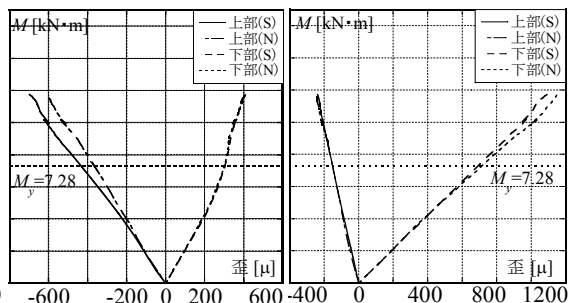

(b) 端部ブロック
図 $5 \mathrm{~S} 100 \mathrm{~L}$ 各部の曲げモーメント一歪関係

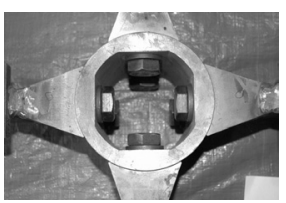

(a) 載荷前

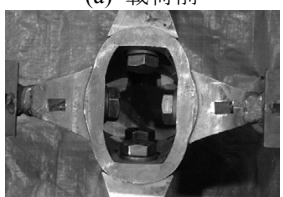

(b) 載荷後 (除荷後)

写真 2 載荷前後の 接合部ノード(S150S)

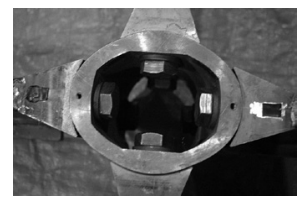

(a) $\mathrm{S} 200 \mathrm{~S}$ 裏面 亀裂

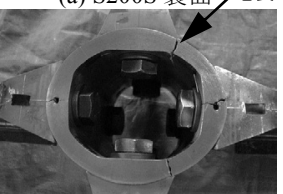

(b) D200S 裹面

写真 3 ノード鋼材

による差異

(除荷後)

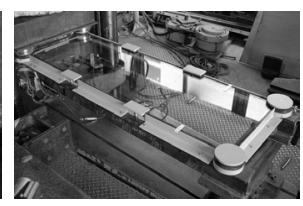

(a) 載荷前

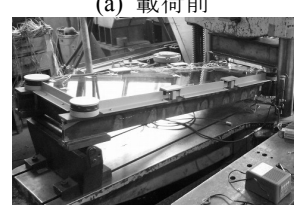

(b) 載荷後 (除荷直前) 写真 4 載荷前後の ガラス付試験体

(S100G)
表 4 面外曲げ試験体の剛性および而力

\begin{tabular}{|c|c|c|c|c|c|}
\hline 試験体名 & $\begin{array}{c}h_{b}[\mathrm{~mm}] \\
(d[\mathrm{~mm}])\end{array}$ & $\begin{array}{c}K_{e l} \\
{[\mathrm{kN} \cdot \mathrm{m} / \mathrm{rad}]}\end{array}$ & $\begin{array}{c}K_{p l} \\
{[\mathrm{kN} \cdot \mathrm{m} / \mathrm{rad}]}\end{array}$ & $\begin{array}{c}M_{y} \\
{[\mathrm{kN} \cdot \mathrm{m}]}\end{array}$ & $\begin{array}{c}M_{p} \\
{[\mathrm{kN} \cdot \mathrm{m}]}\end{array}$ \\
\hline \hline $\mathrm{S} 100 \mathrm{~S}$ & $100(50)$ & 1210 & 31.2 & 7.92 & 10.4 \\
\hline D100S & $100(50)$ & 968 & 72.3 & 8.96 & 11.8 \\
\hline $\mathrm{S} 150 \mathrm{~S}$ & $150(100)$ & 2530 & 107 & 17.0 & 22.8 \\
\hline S200S & $200(150)$ & 5060 & 230 & 25.1 & 32.4 \\
\hline D200S & $200(150)$ & 4590 & 356 & 31.2 & 42.0 \\
\hline S100L & $100(50)$ & 984 & 34.0 & 7.28 & 8.78 \\
\hline D100L & $100(50)$ & 799 & 56.1 & 8.67 & 10.9 \\
\hline S200L & $200(150)$ & 5070 & 173 & 25.4 & 35.6 \\
\hline D200L & $200(150)$ & 4350 & 400 & 30.1 & 40.0 \\
\hline S100NG & $100(50)$ & 2520 & 110 & 7.74 & 10.1 \\
\hline S100G & $100(50)$ & 3190 & 92.5 & 8.17 & 10.3 \\
\hline
\end{tabular}

※S100NG, S100G は 2 列, その他の試験体は 1 列

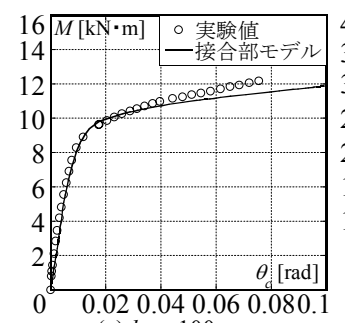

(a) $h_{b}=100 \mathrm{~mm}$

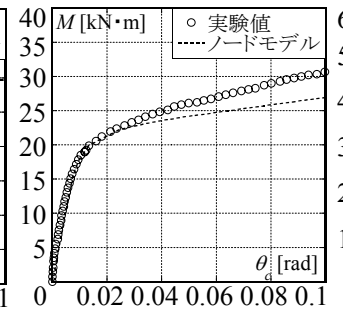

(b) $h_{b}=150 \mathrm{~mm}$

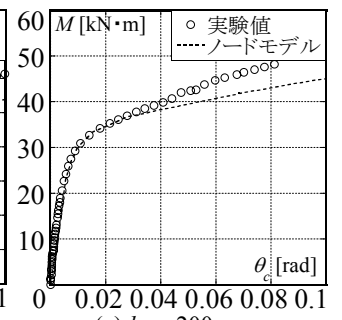

(c) $h_{b}=200 \mathrm{~mm}$

図 7 面外曲げ試験の実験值と解析值 $\left(M-\theta_{c}\right.$ 関係 $)$ 
図 7 に実験值と解析值の $M-\theta_{c}$ 関係の比較を, 表 5 に GY 法によ り求めた解析モデルの剛性および耐力を示す。S100S を模擬した接 合部モデルは，実験の $M-\theta_{c}$ 関係をほぼ模擬できていることがわか る。また, 図 8 に示すように接合部ノードの降伏が先行し, 実験結 果とよい対応を示している。ノードモデルの $K_{e l}$ や $M_{y}$ は実験值と近 い值をとり，降伏時までの挙動は実験結果とよく整合しているが， 二次剛性は，実験值や接合部モデルより小さい值となっており，端 部ブロックによる拘束が影響しているものと思われる。

接合部の設計用回転剛性・耐力を求めるために，円筒モデルに基 づく簡単な力学モデルによる表現を試みる。図 9 に示すリング式を 用い, 面外曲げでは, 偶力が支圧としてボルト位置に作用すると仮 定する。式(1a)，(1b)および図 9 中の各式により円筒モデルの一次剛 性 $K_{e l 0}$, 降伏曲げモーメント $M_{y 0}$ の評価を行う。

$$
\begin{aligned}
& K_{e l 0}=\alpha \frac{M}{\delta / d} \cdots \cdots(1 \mathrm{a}) \quad M_{y 0}=\beta \frac{A_{e q} \sigma_{y} d}{K} \cdots \cdots(1 \mathrm{~b}) \\
& {\left[A_{e q}=\frac{t \cdot h_{n}}{2}, \quad \alpha=\frac{1850}{h_{n} \sqrt{d}}, \quad \beta=\frac{130}{h_{n}}, \quad \phi=71.95^{\circ}\right. \text { (ボルト縁) }}
\end{aligned}
$$

上評価式と実験・解析の比較を図 10 に示す。ボルト間距離 $d$ につ いて整理すると， $K_{e l 0}$ は $d$ の概ね 1.5 乗に比例し， $M_{v 0}$ は $d$ にほぼ比 例する。リング式の $K_{e l 0}, M_{y 0}$ は円筒モデルの解析值とほぼ一致する が, 実験值の $K_{e l}, M_{y}$ はノード形状および端部ブロックの拘束効果 によりそれぞれほぼ一定の割合で増加する。以上より接合部の面外 曲げに対する $K_{e l}$ および $M_{y}$ の評価式を式(2), (3)で定める。

$$
\begin{aligned}
& K_{e l}=2.1 \times K_{e l 0} \quad \cdots \cdots(2 \mathrm{a}) \quad M_{y}=1.3 \times M_{y 0} \quad \cdots \cdots(3 \mathrm{a}) \\
& \text { (薄型ノード } \left.\left(h_{b}=100 \mathrm{~mm}\right) \cdot \mathrm{M} 20\right) \\
& K_{e l}=2.4 \times K_{e l 0} \\
& M_{y}=1.5 \times M_{y 0} \quad \cdots \cdots(3 \mathrm{~b})
\end{aligned}
$$

(厚型ノード $\left.\left(h_{b}=150,200 \mathrm{~mm}\right) \cdot \mathrm{M} 22\right)$

\section{3 面内曲げ試験}

図 3(b)の面内曲げ試験の結果得られた $M-\theta_{c}$ 関係を図 11 に, 試験 体 S100W 各部の曲げモーメント一歪関係を図 12 に, 載荷前後の接 合部を写真 5 に示す。各試験体とも, $M=4 \sim 5 \mathrm{kN} \cdot \mathrm{m}$ 程度で剛性の低 下を生じた。その際, 図 12(c)のように端部ブロック下部の歪増加も 停止しており，ノードと端部ブロックに離間が生じたことがわかる。 接合部降伏後はノードと端部ブロック上部に歪が集中するが，どの 試験体も最大耐力後 $\theta_{c}=0.15 \mathrm{rad}$ 前後でボルト破断で終局状態に至 った。 $l_{b}=300 \mathrm{~mm}$ と短い試験体においてもノードの曲げ降伏が先行し ていることから，面内せん断に対する影響は小さいと考えられる。 面外曲げ試験同様，GY 法を援用し剛性および而力の算出を行う。 面内曲げ試験においては, 図 12(c)に見るように, ボルトの離間後に 挙動が大きく変化するため, 第一折れ点での值を離間曲げモーメン 卜 $M_{s}$, 第二折れ点での值を降伏曲げモーメント $M_{y}$ とする。得られ た結果を表 6 に示す。

面内曲げについても, 有限要素法による解析を行う。解析は, ボ

表 6 面内曲げ実験結果の剛性および耐力

\begin{tabular}{|c|c|c|c|c|c|}
\hline 試験体名 & $\begin{array}{c}h_{b}[\mathrm{~mm}] \\
(d[\mathrm{~mm}])\end{array}$ & $\begin{array}{c}K_{e l} \\
{[\mathrm{kN} \cdot \mathrm{m} / \mathrm{rad}]}\end{array}$ & $\begin{array}{c}K_{p l} \\
{[\mathrm{kN} \cdot \mathrm{m} / \mathrm{rad}]}\end{array}$ & $\begin{array}{c}M_{s} \\
{[\mathrm{kN} \cdot \mathrm{m}]}\end{array}$ & $\begin{array}{c}M_{y} \\
{[\mathrm{kN} \cdot \mathrm{m}]}\end{array}$ \\
\hline \hline $\mathrm{S} 100 \mathrm{~W}$ & $100(50)$ & 612 & 31.2 & 4.37 & 10.5 \\
\hline $\mathrm{D} 100 \mathrm{~W}$ & $100(50)$ & 714 & 16.9 & 5.03 & 13.2 \\
\hline $\mathrm{S} 150 \mathrm{~W}$ & $150(100)$ & 624 & 28.2 & 6.58 & 16.1 \\
\hline $\mathrm{S} 200 \mathrm{~W}$ & $200(150)$ & 547 & 55.9 & 4.34 & 16.3 \\
\hline $\mathrm{D} 200 \mathrm{~W}$ & $200(150)$ & 551 & 21.5 & 6.19 & 17.0 \\
\hline
\end{tabular}

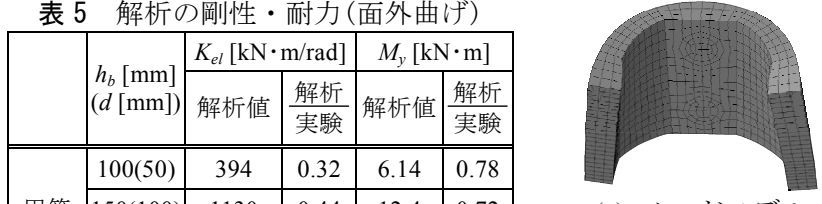

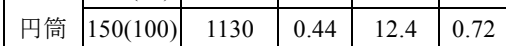

\begin{tabular}{|c|c|c|c|c|c|}
\hline \multirow{3}{*}{} & $200(150)$ & 2180 & 0.43 & 18.1 & 0.72 \\
\hline \multirow{3}{*}{} & $100(50)$ & 543 & 0.44 & 7.72 & 0.97 \\
\cline { 2 - 6 } & $150(100)$ & 2240 & 0.89 & 18.4 & 1.08 \\
\cline { 2 - 6 } & $200(150)$ & 4620 & 0.91 & 27.5 & 1.09 \\
\hline 接合部 & $100(50)$ & 1040 & 0.86 & 8.34 & 1.05 \\
\hline
\end{tabular}

(b) 接合部モデル

図 8 面外曲げノード部変形図

ノードが降伏

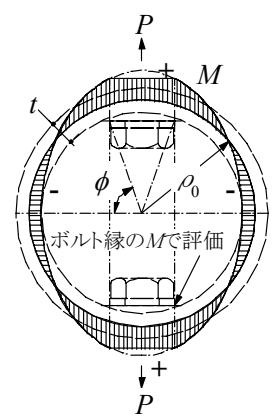

$t=15[\mathrm{~mm}]$ (ノード最薄部厚さ), $\rho_{0}=67.5[\mathrm{~mm}]$

ノード高さ $h_{n}=h_{b}+10[\mathrm{~mm}]$

ボルト間距離 $d=h_{b}-50[\mathrm{~mm}]$

$\kappa=\frac{\rho_{0}}{t} \log \left(\frac{\rho_{0}+t / 2}{\rho_{0}-t / 2}\right)-1$ : 形状係数(矩形)

$K=\left[\frac{1}{\pi(1+\kappa)}+\frac{1}{\kappa}\left\{\frac{1}{\pi(1+\kappa)}-\frac{1}{2} \cos \phi\right\} \frac{-t / 2}{\rho_{0}-t / 2}-\frac{1}{2} \cos \phi+\frac{l}{4 \rho_{0}}\left(1+\frac{1}{\kappa} \times \frac{-t / 2}{\rho_{0}-t / 2}\right)\right]$ $\delta=\frac{M}{d} \cdot \frac{\rho_{0}}{\kappa E A_{e q}}\left\{\frac{\pi}{4}-\frac{2}{\pi}+\frac{2 \kappa}{\pi(1+\kappa)}\right\}:$ 最大たわみ( $\phi=90^{\circ}$ 位置)

図 9 リング式(面外曲げ)

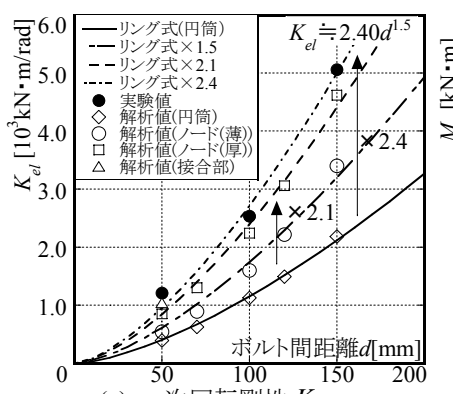

(a) 一次回転剛性 $K_{e l}$

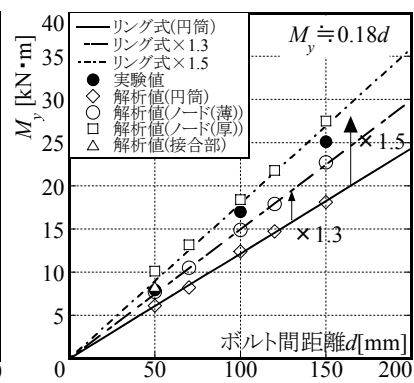

(b) 降伏曲げモーメント $M_{y}$

図 10 一次回転剛性および降伏曲げモーメントの推定
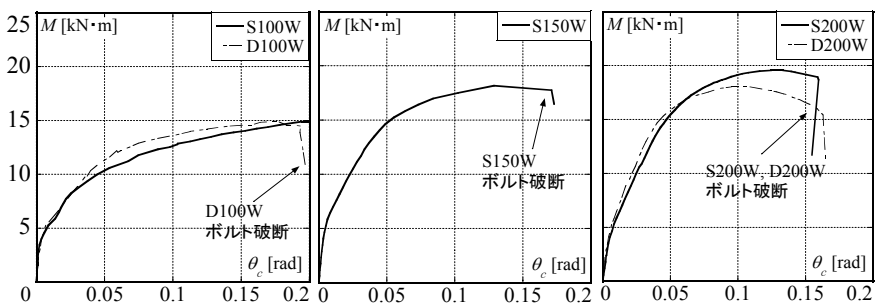

(a) $h_{b}=100 \mathrm{~mm}$

(b) $h_{b}=150 \mathrm{~mm}$

(c) $h_{b}=200 \mathrm{~mm}$

図 11 面内曲げ試験体 $\sigma M-\theta_{c}$ 関係

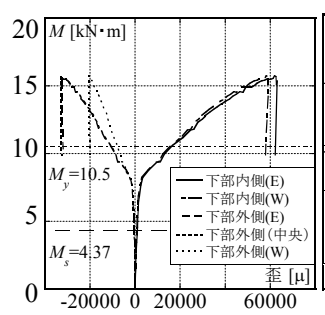

(a) 接合部ノード

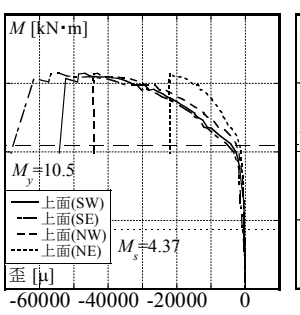

(b) 端部ブロック上部

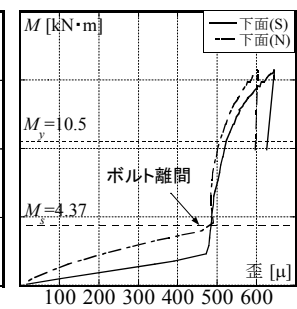
(c) 端部ブロック下部 図 $12 \mathrm{~S} 100 \mathrm{~W}$ 各部の曲げモーメント一歪関係

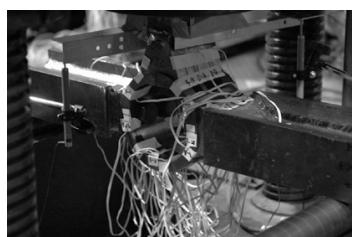

(a) 載荷前

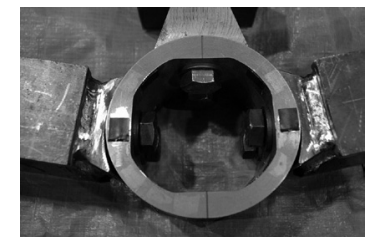

(b) 載荷後（除荷後） 写真 5 載荷前後の試験体(D100W) 
ルトの影響を加味する必要から,接合部モデルについてのみ行った。 図 13 に実験值と解析值の $M-\theta_{c}$ 関係の比較を, 表 7 に GY 法により 求めた解析モデルの剛性および耐力を示す。各梁せいごとの接合部 モデルにより, ボルト離間による剛性低下は再現できないものの, 実験の $M-\theta_{c}$ 関係をおおよそ再現できている。図 14 に示すように, $h_{b}=100 \mathrm{~mm}$ のモデルでは接合部ノードの降伏が先行し, $h_{b}=200 \mathrm{~mm}$ の モデルではボルトの降伏が先行する。

面内曲げについても，リング式による回転剛性および耐力の算定 を試みる。図 15 に示すように, ノードは梁材との連結位置でモーメ ントを受けるものとし，ボルトは，てこ反力として端部ブロックの 先端とボルト位置に発生する偶力と, せん断力を受けるものと仮定 する。但し, 回転剛性 $K_{e l}$ については, 接合部モデル(薄)の解析值を 最小二乗法により線形近似して算出する。

ここでは，式(4)，(5)および図 15 中の各式により接合部モデルの 一次剛性 $K_{e l}$, 降伏曲げモーメント $M_{y}$ の評価を行う。

$$
\begin{aligned}
& K_{e l}=0.91 d+420 \text { (4) } M_{y}=\min \left\{\beta \frac{\pi \rho_{0} A_{e q} \sigma_{y}}{K}, \frac{A_{s} f_{t} d_{l}\left(l_{b}-l_{n}\right)}{\sqrt{3} d_{l}+l_{b}-l_{n}}\right\} \\
& {\left[A_{e q}=t \cdot d, \quad \beta=\frac{26}{d^{0.25}}\right]}
\end{aligned}
$$

上評価式と実験・解析の比較を図 16 に示寸。解析值の $K_{e l}$ は，実 験值の一次剛性と二次剛性の平均値と概ねよい対応を示す。ボルト 間距離 $d$ について整理すると,ノードの $M_{y}$ は $d$ の概ね 0.75 乗に比 例し，ボルトの $M_{y}$ で頭打ちになる。ボルト径 M22 を用いた厚型の 接合部の $M_{y}$ は，ノード形状・ボルト径の違いにより，ノードでは 薄型の概ね 1.1 倍，ボルトでは 1.2 倍となる。以上より接合部の面 内曲げに対する $K_{e l}$ と $M_{y}$ を式(4)，(5)で評価する。

\section{4 圧縮試験}

図 3(c)の圧縮試験の結果得られた軸力一変位関係 $(P-\delta$ 関係)を図 17 に，試験体 $\mathrm{S} 100 \mathrm{C}$ 接合部ノードの軸力一歪関係を図 18 に示寸。 接合部の降伏とほぼ同時に接合部ノードの歪が急増しており，接合 部の耐力はノードで決定される。接合部ノードの降伏後には荷重が 頭打ちとなり, 写真 6 に見るように接合部ノードの変形が増大して いく。鋼材ノードは十分な変形性能を示したが，鋳鉄のノード D100C, D200C は, 変形 8～10mm で写真 7 に見るような亀裂がノ ードに発生し耐力低下を生じた。

GY 法により, 剛性および耐力を算出する。圧縮試験においては, 第一折れ点での值を降伏耐力 $P_{y}$ とし, 第二折れ点での值を終局耐力 $P_{p}$ とした。得られた結果を表 8 に示す。

圧縮試験についても，面外曲げと同様の 3 つのモデルを用い，有 限要素法による解析を行う。図 19 に, 実験值と解析值の $P-\delta$ 関係 の比較を, 表 9 に GY 法により求めた解析モデルの剛性・耐力を示 す。圧縮でも, $\mathrm{S} 100 \mathrm{C}$ は接合部モデルにより, 実験の $P-\delta$ 関係を 模擬できた。図 20 に示寸ように, 圧縮でもノードに歪が集中するこ とがわかる。一方，S200C では，ノードモデルの $K_{e l}$ は実験值に近

表 8 圧縮試験体の剛性および而力

\begin{tabular}{|c|c|c|c|c|c|}
\hline 試験体名 & $\begin{array}{c}h_{b}[\mathrm{~mm}] \\
(d[\mathrm{~mm}])\end{array}$ & $\begin{array}{c}K_{e l} \\
{[\mathrm{kN} / \mathrm{mm}]}\end{array}$ & $\begin{array}{c}K_{p l} \\
{[\mathrm{kN} / \mathrm{mm}]}\end{array}$ & $\begin{array}{c}P_{y} \\
{[\mathrm{kN}]}\end{array}$ & $\begin{array}{c}P_{p} \\
{[\mathrm{kN}]}\end{array}$ \\
\hline \hline $\mathrm{S} 100 \mathrm{C}$ & $100(50)$ & 265 & 12.7 & 201 & 250 \\
\hline $\mathrm{D} 100 \mathrm{C}$ & $100(50)$ & 205 & 14.4 & 251 & 346 \\
\hline $\mathrm{S} 200 \mathrm{C}$ & $200(150)$ & 648 & 22.3 & 670 & 843 \\
\hline $\mathrm{D} 200 \mathrm{C}$ & $200(150)$ & 531 & 30.7 & 581 & 774 \\
\hline
\end{tabular}
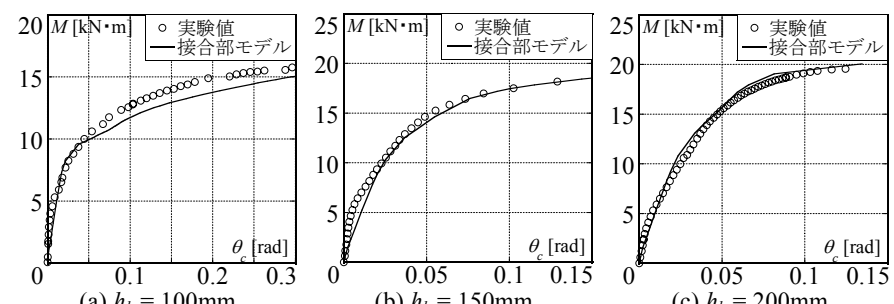

(a) $h_{b}=100 \mathrm{~mm}$

(b) $h_{b}=150 \mathrm{~mm}$

(c) $h_{b}=200 \mathrm{~mm}$

図 13 面内曲 $゙ ゙$ 試験の解析值と実験值 $\left(M-\theta_{c}\right.$ 関係)

\begin{tabular}{|c|c|c|c|c|c|}
\hline & \multirow[b]{2}{*}{$\begin{array}{l}h_{b}[\mathrm{~mm}] \\
(d[\mathrm{~mm}])\end{array}$} & \multicolumn{2}{|c|}{$K_{e l}[\mathrm{kN} \cdot \mathrm{m} / \mathrm{rad}]$} & \multicolumn{2}{|c|}{$M_{y}[\mathrm{kN} \cdot \mathrm{m}]$} \\
\hline & & 解析値 & $\begin{array}{l}\text { 解析 } \\
\text { 実験 }\end{array}$ & 解析值 & $\begin{array}{l}\text { 解析 } \\
\text { 実験 }\end{array}$ \\
\hline \multirow{3}{*}{\begin{tabular}{|c} 
接合部 \\
(薄)
\end{tabular}} & 10 & 453 & 0.74 & 8.81 & 0.84 \\
\hline & $150(1$ & 517 & 0.82 & 13.8 & 0.86 \\
\hline & $200(150)$ & 547 & 1.00 & 15.7 & 0.96 \\
\hline \multirow{3}{*}{\begin{tabular}{|c} 
接合部 \\
$($ 厚 $)$
\end{tabular}} & $100(50)$ & דוד & 0.77 & 10.8 & 1.00 \\
\hline & $150(100)$ & 497 & 0.80 & 16.4 & 1.02 \\
\hline & $200(150)$ & 529 & 0.97 & 17.9 & 1.09 \\
\hline
\end{tabular}

表 7 解析の剛性・耐力 (面内曲げ) ードに

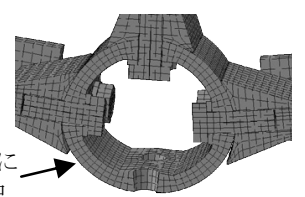

(a) S100W 接合部モデル

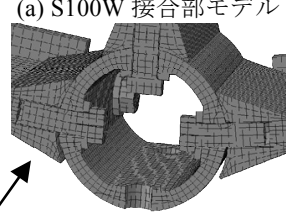

ボルトに (b) S200W 接合部モデル 図 14 面内曲げ

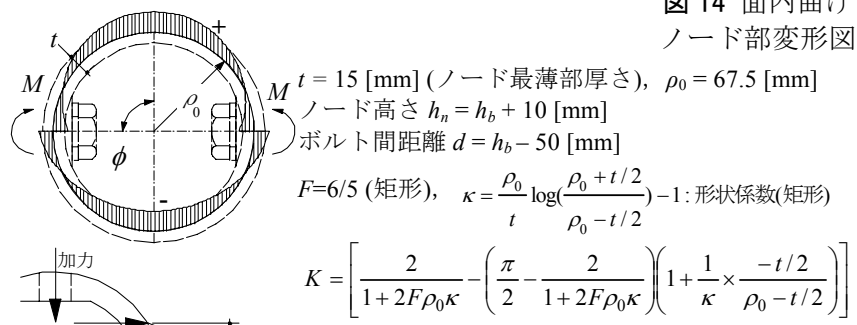

圧縮 $A_{s}$ : ボルト有効断面積, $f_{t}$ : ボルト降伏応力

てこ反力腕長さ $d_{l}=40[\mathrm{~mm}]$

引張四せん断力 $l_{b}$ : 梁材長さ, $l_{n}:$ ノード外径

図 15 リング式(面内曲げ)

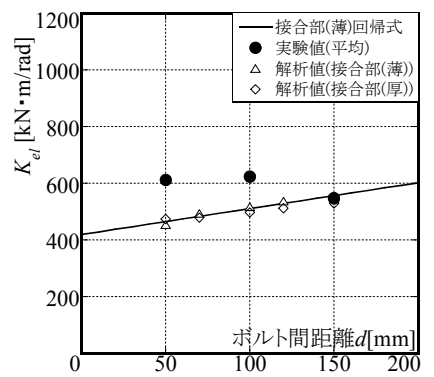

(a) 一次回転剛性 $K_{e l}$

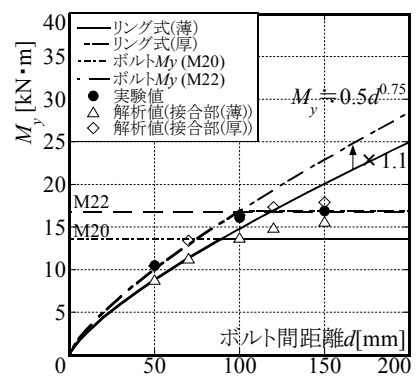

(b) 降伏曲げモーメント $M_{y}$

図 16 一次回転剛性および降伏曲げモーメントの推定

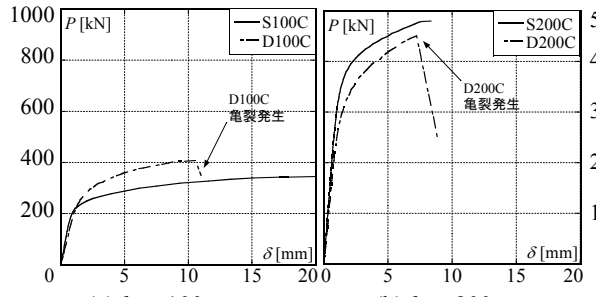

(a) $h_{b}=100 \mathrm{~mm}$

図 17 圧縮試験体の $P-\delta$ 関係

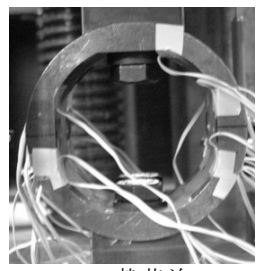

(a) 載荷前 写真 6 試験前後の接合部ノード(S100C)

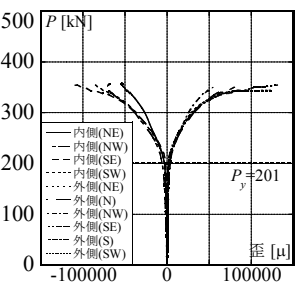

図 $18 \mathrm{~S} 100 \mathrm{C}$ 接合部 ノードの軸力一歪関係

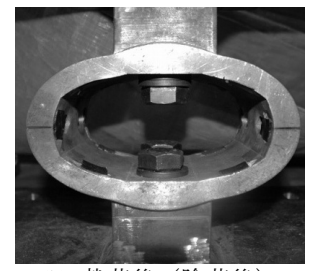

(b) 載荷後 (除荷後)

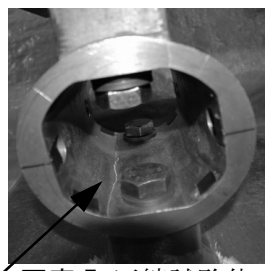

写真 7 圧縮試験体 D200C 亀裂 
い值をとったが， $P_{y}$ は実験值より小さい值をとった。これは，端部 ブロックの拘束効果をモデル化していないことによるものと考えら れる。

圧縮試験についても, リングモデルによる剛性および耐力の評価 を試みる。圧縮試験では，端部ブロックとノードの接触部分に分布 力が作用するものと仮定し, 式(6a), (6b)および図 9 中の各式により 円筒モデルの一次剛性 $K_{e l 0}$, 降伏軸力 $P_{y 0}$ の評価を行う。

$$
\begin{array}{ll}
K_{e l 0}=\alpha \frac{M}{\delta / d} \cdots \cdots(6 \mathrm{a}) & P_{y 0}=\beta \frac{A \sigma_{y}}{K} \cdots \cdots(6 \mathrm{~b}) \\
{\left[A_{e q}=t \cdot h_{n}, \quad \alpha=\beta=1.13,\right.} & \left.\phi=77.96^{\circ}(\text { 端部ブロック端 })\right]
\end{array}
$$

上評価式と実験・解析の比較を図 21 に示す。ノード高さ $h_{n}$ につ いて整理すると， $K_{e l 0}, P_{y 0}$ はともに $h_{n}$ にほぼ比例していることがわ かる。リング式の $K_{e l 0}, P_{y 0}$ は円筒モデルの解析值とほぼ一致する。 実験值の $K_{e l}, P_{y}$ はノード形状の効果により，それぞれほぼ一定の割 合で増加している。以上より接合部の圧縮に対する $K_{e l}$ および $P_{y}$ の 評価式を式(7), (8)で定める。 $h_{b}=200 \mathrm{~mm}$ での $P_{y}$ 評価值は実験值に比 べ小さいが，安全側となる。

$$
\begin{array}{lll}
K_{e l}=1.7 \times K_{e l 0} & \cdots \cdots(7 \mathrm{a}) & P_{y}=1.7 \times P_{y 0} \quad \cdots \cdots(8 \mathrm{a}) \\
& & \left(\text { 薄型ノード }\left(h_{b}=100 \mathrm{~mm}\right) \cdot \mathrm{M} 20\right) \\
K_{e l}=2.0 \times K_{e l 0} & \cdots \cdots(7 \mathrm{~b}) \quad \begin{array}{l}
P_{y}=2.0 \times P_{y 0} \quad \cdots \cdots(8 \mathrm{~b}) \\
\end{array} & \left(\text { 厚型ノード }\left(h_{b}=150,200 \mathrm{~mm}\right) \cdot \mathrm{M} 22\right)
\end{array}
$$

\section{5 引張試験}

図 3(d)の引張試験の結果得られた $P-\delta$ 関係を図 22 に, 試験体 S100T 各部の軸力一歪関係を図 23 に示す。引張試験体はノードの降 伏後も一定の剛性を持って荷重が増大した。写真 8 , 図 23 に見るよ うに，変形は接合部ノードに集中し，ここでもノードが接合部の降 伏耐力を決定している。鋳鉄ノード D $100 \mathrm{~T}$ はノードに亀裂が発生す ることにより耐力が低下し, 他の試験体はボルトの最大軸力に到達 した後, 写真 9 に見るように, ボルトが破断することにより終局状 態に達した。

ボルトおよび梁材の伸びを考慮し，GY 法を援用して接合部の剛 性および耐力を算出する。引張試験においても, 第一折れ点での值 を降伏耐力 $P_{y}$ とし, 第二折れ点での值を終局耐力 $P_{p}$ とした。得ら れた結果を表 10 に示す。

引張試験についても, 面外曲げと同様の 3 モデルを用い, 有限要 素法による解析を行う。図 24 に, 実験值と解析值の $P-\delta$ 関係の比 較を, 表 11 に GY 法により求めた各解析モデルの剛性および而力を 示す。引張では, 図 24 に見るように, S100T を模擬した接合部モデ ルにより, 実験の $P-\delta$ 関係はほぼ模擬できる。図 25 に見るように, 降伏時にはノードに歪が集中し，実験と対応する。ノードモデルで の $K_{e l}$ や $P_{y}$ は実験值に近い值をとり, 降伏時までの挙動を十分模擬 できている。

引張試験について, リングモデルによる剛性および耐力の評価を 試みる。引張試験ではボルト軸部に分布力が作用するものと仮定す る。式(9a), (9b)および図 9 中の各式により円筒モデルの一次剛性 表 10 引張実験結果の剛性および耐力

\begin{tabular}{|c|c|c|c|c|c|}
\hline 試験体名 & $\begin{array}{c}h_{b}[\mathrm{~mm}] \\
(d[\mathrm{~mm}])\end{array}$ & $\begin{array}{c}K_{e l} \\
{[\mathrm{kN} / \mathrm{mm}]}\end{array}$ & $\begin{array}{c}K_{p l} \\
{[\mathrm{kN} / \mathrm{mm}]}\end{array}$ & $\begin{array}{c}P_{y} \\
{[\mathrm{kN}]}\end{array}$ & $\begin{array}{c}P_{p} \\
{[\mathrm{kN}]}\end{array}$ \\
\hline \hline $\mathrm{S} 100 \mathrm{~T}$ & $100(50)$ & 221 & 9.38 & 151 & 179 \\
\hline $\mathrm{D} 100 \mathrm{~T}$ & $100(50)$ & 244 & 11.4 & 180 & 241 \\
\hline $\mathrm{S} 200 \mathrm{~T}$ & $200(150)$ & 428 & 12.7 & 441 & 518 \\
\hline $\mathrm{D} 200 \mathrm{~T}$ & $200(150)$ & 292 & 11.7 & 424 & 501 \\
\hline
\end{tabular}

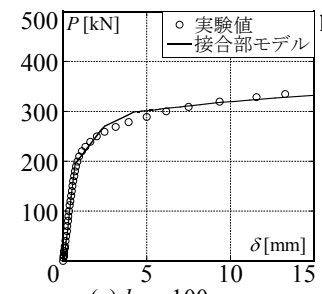

(a) $h_{b}=100 \mathrm{~mm}$

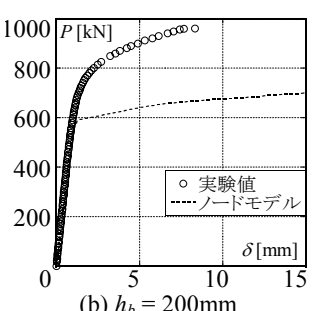

(b) $h_{b}=200 \mathrm{~mm}$
ノードに 歪集中
図 19 圧縮試験の解析值と実験值 $(P-\delta$ 関係 $)$

表 9 解析の剛性・耐力 (圧縮)

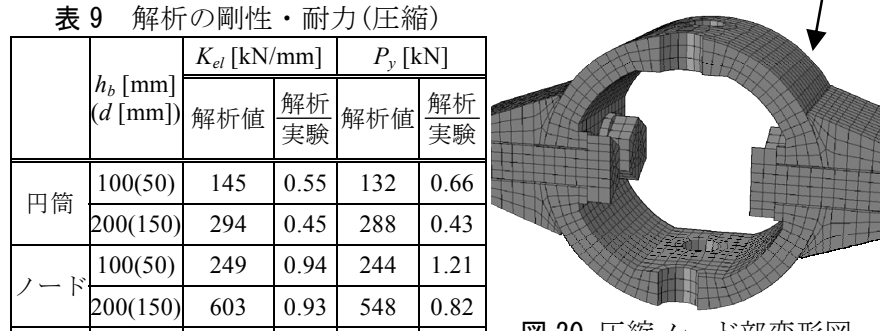

図 20 圧縮ノード部変形図 (接合部モデル)

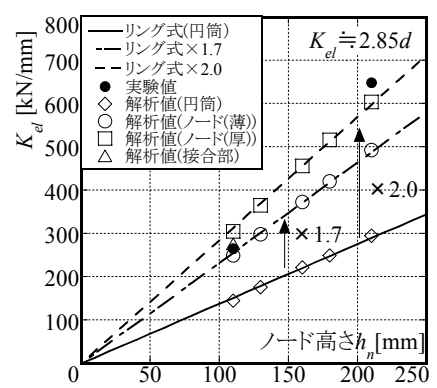

(a) 一次剛性 $K_{e l}$

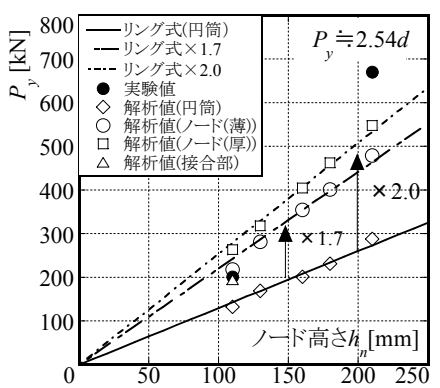

(b) 降伏軸力 $P$
図 21 一次剛性および降伏軸力の推定

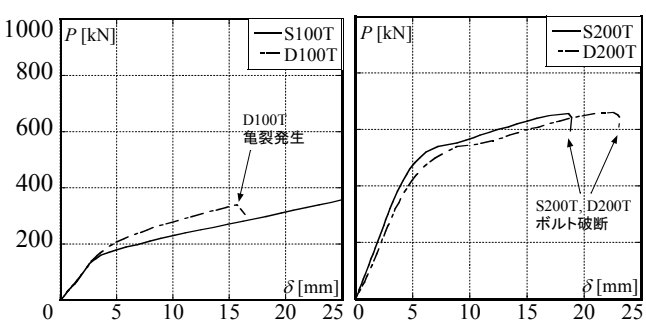

$\begin{array}{ll}\text { (a) } h_{b}=100 \mathrm{~mm} & \text { (b) } h_{b}=200 \mathrm{~mm}\end{array}$

図 22 引張試験体の $P-\delta$ 関係

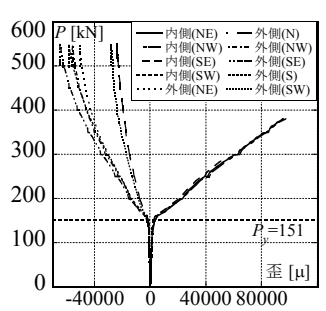

(a) 接合部ノード

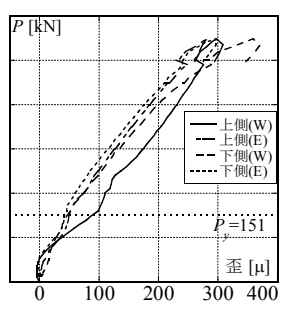

(b) 端部ブロック

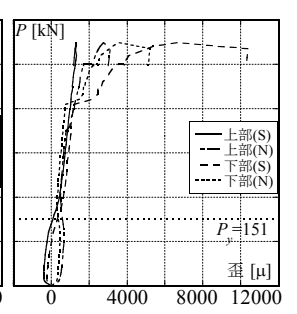

(c) 梁材
図 $23 \mathrm{~S} 100 \mathrm{~T}$ 各部の曲げモーメント一歪関係

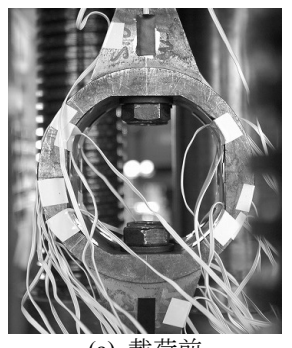

(a) 載荷前

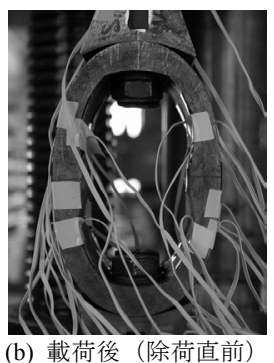

（b）載荷後 (除荷直前)

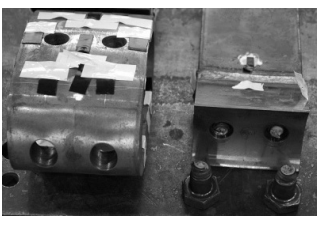

写真 9 引張試験体 ボルト破断(S100T) 
$K_{e l 0}$, 降伏軸力 $P_{y 0}$ の評価を行う。

$$
\begin{aligned}
& K_{e l 0}=\alpha \frac{M}{\delta / d} \cdots \cdots(9 \mathrm{a}) \quad P_{y 0}=\beta \frac{A \sigma_{y}}{K} \cdots \cdots(9 \mathrm{~b}) \\
& {\left[A_{e q}=t \cdot d, \quad \alpha=\sqrt{\frac{336}{d}}, \quad \beta=\sqrt{\frac{183}{d}}, \quad \phi=81.57^{\circ} \text { (ボルト軸部) }\right]}
\end{aligned}
$$

上評価式と実験・解析の比較を図 26 に示す。ボルト間距離 $d$ につ いて整理すると， $K_{e l 0}, P_{y 0}$ はともに $d$ の概敉 0.5 乗に比例する。リ ング式の $K_{e l 0}, P_{y 0}$ は円筒モデルの解析值とほぼ一致し, 実験值の $K_{e l}$, $P_{y}$ はノード形状の効果により, それぞれほぼ一定の割合で増加して いる。以上より接合部の引張に対する $K_{e l}$ および $P_{y}$ の評価式を式(10), (11)で定める。

$$
\begin{aligned}
& K_{e l}=1.7 \times K_{e l 0} \\
& P_{y}=1.7 \times P_{y 0} \\
& K_{e l}=2.0 \times K_{e l 0} \\
& P_{y}=2.0 \times P_{y 0} \quad \cdots \cdots(11 \mathrm{~b})
\end{aligned}
$$

(厚型ノード $\left.\left(h_{b}=150,200 \mathrm{~mm}\right) \cdot \mathrm{M} 22\right)$

\section{3. 中空円筒型接合部を用いたドームの試設計}

最後に，以上の実験・解析で評価した中空円筒型接合部を用いて 構成される単層直交格子シェル構造物を例題とし, 得られた接合部 剛性がシェル構造物全体の座屈荷重に与える影響を検討する。

対象とする構造物は, 図 27 に示す, スパン $L=20 \mathrm{~m}$, 半開角 $\theta=30^{\circ}$ の単層直交格子ドームであり, 表 12 の部材および $h_{b}=100 \mathrm{~mm}$ の中 空円筒型接合部により構成する。格子はガラスを受けるために部材 長 $l_{0}$ が $1500 \mathrm{~mm}$ 以下となるように分割する。この単層直交格子ドー ムに対して，接合部を剛接合として計算したモデルと，中空円筒型 接合部の使用を想定し式(2a)で得た面外回転剛性を持つ半剛接合と したモデルについて, 自重相当の鉛直荷重 $\left(P_{0}=1.18 \mathrm{kN} / \mathrm{m}^{2}\right)$ に対する 線形固有值解析により線形座屈荷重 $P_{c r}^{l i n}$ を算出する。また, 得られ た值を加藤ら ${ }^{1)}$ の線形座屈荷重の推定式(12) と比較する。

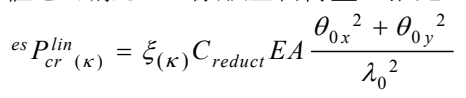

解析結果を図 28 および表 13 に示す。半剛接モデルの座屈荷重は 剛接モデルに対して解析值で 0.40 倍, 推定式で 0.47 倍程度となり, 回転剛性が座屈荷重に与える影響が大きいことがわかる。ただし, 接合部剛性を考慮しても, 本モデルの線形座屈荷重は自重に対し 10 倍程度の余裕を持った值となる。推定式(12)は解析值と同様の傾向 を示し, ほぼ妥当な結果が得られている。

\section{4. 結}

中空円筒型の単層直交格子シェル用接合部を設定し，各方向に対 する剛性・耐力を実大単調載荷実験および有限要素法解析により求 めた。得られた結果を以下に要約する。

1) 面外曲げ，面内曲げ，圧縮，引張共に，円筒型ノードの塑性化が 先行し，塑性変形性能に富んだ荷重一変形関係が得られた。 なお，面内曲げ，引張荷重下の最終荷重はボルト破断となった。

2) 各方向の剛性・耐力は接合部を模擬した有限要素法解析で概ね再 現でき，リング式を元にそれぞれ単純な近似式で表現できた。

\begin{tabular}{|c|c|c|c|c|c|}
\hline & \multirow{2}{*}{$\begin{array}{l}h_{b}[\mathrm{~mm}] \\
(d[\mathrm{~mm}])\end{array}$} & \multicolumn{2}{|c|}{$K_{e l}[\mathrm{kN} / \mathrm{mm}]$} & \multicolumn{2}{|c|}{$P_{y}[\mathrm{kN}]$} \\
\hline & & 解析値 & $\begin{array}{l}\text { 解析 } \\
\text { 実験 }\end{array}$ & 解析值 & $\begin{array}{l}\text { 解析 } \\
\text { 実験 }\end{array}$ \\
\hline \multirow{2}{*}{ 円筒 } & $100(50)$ & 116 & 0.52 & 105 & 0.70 \\
\hline & $200(150)$ & 207 & 0.48 & 192 & 0.44 \\
\hline \multirow{2}{*}{ ノード } & $100(50)$ & 204 & 0.92 & 169 & 1.12 \\
\hline & $200(150)$ & 407 & 0.95 & 348 & 0.79 \\
\hline 接合部 & $100(50)$ & 187 & 0.85 & 166 & 1.10 \\
\hline
\end{tabular}

3) 同接合部を用いた $20 \mathrm{~m}$ 級ドームの試設計を行い，接合部剛性が単 層格子シェルの座屈耐力に与える影響を確認した。面外曲げ接合 部剛性によるドームの線形座屈荷重の低下率は約 $0.4 \sim 0.5$ 倍程度 であった。

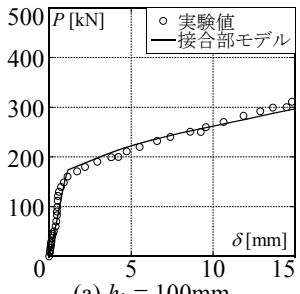

(a) $h_{b}=100 \mathrm{~mm}$

表 11 解析の剛性・耐力 (引張)

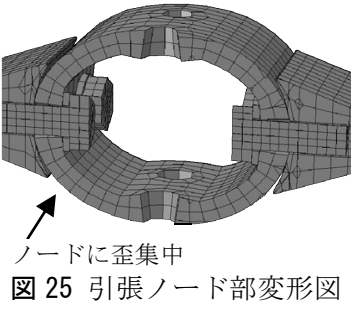
(接合部モデル)

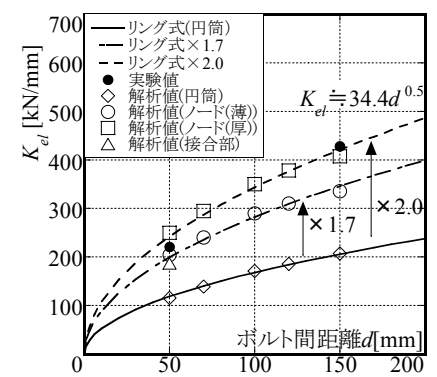

(a) 一次剛性 $K_{e l}$ (b) $h_{b}=200 \mathrm{~mm}$
牦

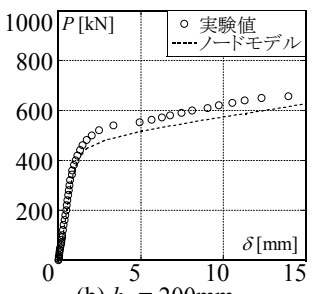

